\title{
Leveraging on Motivation to Retain Employees: The Role of Psychological Contract
}

\author{
Ghulam Ahmed Bin Donkor ${ }^{1}$, Godfrey Adda ${ }^{2} \&$ Mohammed Kweku Baidoo ${ }^{3}$ \\ 1 Department of Business Administration, Ghana Communications Technology University - Accra; and \\ Consultant, Tawheed Group of Companies \& Former Deputy Director, Ahmadiyya Health Service, Ghana \\ ${ }^{2}$ School of Business and Management Studies, Bolgatanga Technical University (BTU), Ghana \\ ${ }^{3}$ Kwame Nkrumah University of Science and Technology, Industrial Art, Kumasi and, Department of Jewellery \\ Design, AsanSka College of Design and Technology, Accra, Ghana \\ Correspondence: Ghulam Ahmed Bin Donkor, Department of Business Administration, Ghana Communications \\ Technology University - Accra; and Consultant, Tawheed Group of Companies \& Former Deputy Director, \\ Ahmadiyya Health Service, Ghana. E-mail: gadonkormission11@gmail.com
}

Received: July 7, 2021

doi:10.5539/ijbm.v16n10p40
Accepted: July 28, 2021

Online Published: August 25, 2021

\begin{abstract}
The migration of nurses in pursuit of 'greener pastures' has been an issue of great concern and a threat to the health sector across the globe, especially the developing nations. Interventions by successive Ghanaian governments to stem the tide have failed because issues surrounding transfer policies, family reunion and career choice trajectories have not been satisfactorily addressed. This empirical study was aimed at identifying the missing links in the motivational interventions in order to proffer suggestions on specific support systems to retain nurses. The study adopted a cross-sectional design under the quantitative methodology to achieve the objective of the study. A questionnaire was used as an instrument to collect primary data from a sample size (n) of 350 nurses from five Mission Hospitals in Bono East Region of Ghana. The data was analyzed using SmartPLS3 structural equation modeling (SEM). The findings revealed that psychological contract plays an important role in stay-or-quit decision of nurses because management's effort at motivating staff is still at odds with the critical elements of nurses' motivational content.
\end{abstract}

Keywords: motivation, psychological contract breach, turnover intentions, mission hospitals and nurses

\section{Introduction}

The migration of nurses in pursuit of 'greener pastures' is a phenomenon that is of great concern and a threat to the health sector across the globe; more especially in developing nations (Duffield et al., 2014; Fragar \& Depczynski, 2011). The problem is much more pronounced with dire consequences in the healthcare delivery sector, particularly in sub-Saharan Africa. It is estimated that in the year 2006, out of 17,322 nurses and midwives who worked in Ghana, 2,267 (representing 13\% ) of them worked in the Organisation for Economic Co-operation and Development (OECD) countries (Fragar \& Depczynski, 2011).

This has contributed to low patient to nurse ratio that stood as 1,537:1 in 2006 (WHO, 2006 in Quartey \& Kwakye, 2008). To buttress this, Quartey \& Kwakye (2008) suggest that poor conditions of service and the liberal immigration policies adopted by the Western countries accounted for the migration of health workers including nurses in Ghana. The migration of nurses in Ghana to other countries, however, occurs in two forms; internal and international. The internal migration has tended to favour movement from the rural communities to the urban centres with the hope of accessing good educational facilities for their children, better career options, good road transportation system, improved housing and less social isolation (Kok et al., 2006). The international migration is more about nurses migrating to the developed nations in search of what has become known as 'greener pastures'. However, irrespective of the form that nurses choose to migrate, the heart of this phenomenon is demographic, career choice and motivational factors.

To curtail these migrations in Ghana, numerous governmental interventions, including additional duty hour allowance (ADHA), car loans, and duty free regimes for vehicles were instituted to stem the tide (Quartey \& Kwakye, 2008). These were tangible measures specifically instituted to motivate nurses to secure their 
commitment to their organization. Notwithstanding the various interventions by governments over the years to improve talent retention, turnover of workers in the health sector has not been stemmed, because issues such as transfer policies, family reunion, career choices and other trajectories, converge to constitute a psychological breach that causes some nurses to migrate or entirely quit their jobs in the Health Sector (Lenthall et al., 2011; Rodwell \& Demir, 2013).

Psychological contract breach is about individual's subjective assessment of fulfilment or non-fulfilment of promised obligation. During this unilateral determination of the status of the employment contract if any of the parties realized that promises, obligations or expectations have not been fulfilled, they either stay the cause, remediate or exit the relationship. Studies have shown that employees and employers, at one time or the other in their exchange relationship have experienced breaches in their psychological contract (Dantas \& Ferreira, 2015; Rodwell \& Ellershaw, 2016), and whenever employees' investments in 'promises' are not fulfilled it draws many undesirable reactions from those who may deem it unfair. One effect is that some employees resort to 'tight-fisting behaviours' by calculating the direct and opportunity cost of the relationship. Those with external locus of control become psychologically hit and end up as 'enemies' to the organizational progress (Fu \& Cheng, 2014). Another effect is that some employees are hit so hard that they become angry, desperate and depraved (Tomprou et al., 2012). Their satisfaction in the job as well as commitment to the organization diminishes; and depending on the impact, they limit their contribution to the organization or refuse to help their colleague staff (Behery, Paton \& Hussain, 2012). Others fail to promote positive attitude, refuse to obey organizational rules, regulations and procedures while others do not make any sincere effort to improve work outcomes. Others too fail to be part of the political membership of their organization, and become indifferent to policy enrichment. And in some extreme cases, some end up severing their relationship with their organization (Tambe \& Shanker, 2014).

Nonetheless, in spite of the existence of many studies in psychological contract breach, less attention has been paid to relational job characteristics relative to work engagement and the role of motivation in employee retention (Rodwell \& Elershaw, 2016; Deboever, 2015). For instance, according to Briner and Conway (2005) the definition criteria for what is inducement and what is contribution have not received much empirical attention. While most of the research in the psychological contract have been done in respect of what the two parties bring onto the table i.e. expectation and inducement, the correlation of the variables or specific items of the exchange agreement have not been researched. Furthermore, whereas there are considerable number of studies which associate organizational success, employee commitment and improved performance with organizational climate, there are few which look at the role of psychological contract in employee retention (Wayland, 2011; Lin \& Chang, 2009).

This study, therefore, aimed at identifying the missing links in motivational interventions in order to address the causes of psychological contract breach that disconnect the relationship between motivation and nurse retention; in order to proffer specific support systems necessary for nurses motivation as well as evaluate the role of psychological contract in stay-or-quit decisions of nurses.

\subsection{Theoretical Foundation and Hypotheses Development}

Extant literature has noted the complexity of human motivation because of varying human expectations, circumstances and experiences (Campbell, 2006). Subsequently, different models including rational economic model, social model, self-actualizing model and complex model were developed (Rowley, 1996). The rational economic model, derived from F.W. Taylor's (1911) "rational economic concept of motivation" assumes that high wages will lead to efficiency and productivity. The social model, however, stresses interpersonal relationship and assumes that people will ordinarily want to associate, engage in social activities and belong to a social group. And just as the self-actualizing model recognizes workers desire to accomplish their worthwhile career goals, the complex model of motivation notes the diversity in human beings. However, all these studies are not any different from the works of seminal works of Maslow, Merzberg etc., and the thinking that for human beings to work at their optimal levels, either internal or external proddings or both are necessary, given that psychological contract has always determined the specific inducement and contribution that workers and employers expect from their exchange relationship.

\subsection{Psychological Contract}

Psychological contract has been conceptualized as mental model of the mutual obligation, as what is owed, as inducement, and as most important of promises (Rousseau, 1989; Freese, 2007: 123). According to Rousseau (1989), psychological contract is about "individual belief regarding the terms and conditions of a reciprocal exchange agreement between the focal person and another party". While 'expectation' formed the basis of the seminal authors' definition, contemporary writers have used 'promises', 'obligation' and 'expectation' interchangeably (Bankins, 2014); and is said to have implicit and explicit denotations (Alcover et al., 2016), 
Psychological contract theory has been extensively used to understand how employment relationship unfolds in a work place environment and as a tool to understand fairness, loyalty, trust and integrity of the parties (Holtz, 2013). For the reason, this can help employers and employees understand others strong emotional and affective currencies behind the veneer of formal employment contracting which, if not well managed could affect organizational outcomes. Walker (2013) states that perception plays important role in how healthcare employees become aware of their responsibilities towards occupational health and safety. Nonetheless, incongruence can arise out of misunderstanding of what was promised and what was delivered in any mutual relations and, if not well managed, could affect employees' motivation levels negatively leading to psychosocial contract violation (Corder \& Ronnie, 2017).

There are four main things which shape the focus of psychological contract. These are transactional, relational, balanced and ideological currencies (Ventilborgh et al., 2015; Schafer \& Festing, 2014). While the focus of transactional variant of psychological contract is about the economic rewards that employees hope to derive from their employment exchange, the relational psychological contract is said to be governed by the doctrines of loyalty or affinity in exchange for job security and recognition (Schafer \& Festing, 2014). Meanwhile, ideological psychological contract relates to organization's mission, vision and principles (Ventilborgh et al., 2015).

Transactional psychological contract has been described as narrow in scope and limited in its application. Meanwhile, relational psychological contract has been described as broader in scope and combined in itself economic attributes. Scheel, Rigotti and Mohr (2013) for instance have argued that transactional and relational variants of psychological contract could be mutually inclusive since some of their elements cut across their respective spectrums; meaning that at any point of the continuum, different categories of employees and employers can identify their psychological contract characteristics.

Psychological contract differs in terms of its strength, focus, timeframe, stability, tangibility and scope; with each addressing different aspects of the psychological contract. O'Leary-Kelly et al. (2014) for instance have described relational psychological contract as humane, socializing and constructive. Transactional psychological contract focuses on immediate rewards that the parties in the relationship receive. This could be monetary rewards for services rendered. Employees exchange their time, effort, skills or initiative for pay, bonuses, extra work allowance and many other tangible items. While the duration of engagement determines whether a psychological contract could pass as either relational or transactional, the employment level also defines the type of psychological contract.

During employment relationship, the parties go through a cognitive or perceptual process to determine whether the perceived obligations, promises and expectations have been met. Psychological contract breach, therefore, is about individual assessment of the 'value' of the relationship, and the determination made on its fulfilment or otherwise. Studies have shown that employees and employers, at one time or the other in their exchange relationship, have experienced breaches in their psychological contract because the very elixir which lubricates the relationship has been jettisoned (Dantas \& Ferreira, 2015; Rodwell \& Ellershaw, 2016). Chenoweth (2014) evinced that nurses are both intrinsically and extrinsically motivated in their job. While intrinsically they are motivated by care giving, work relations and collegiality, extrinsically they were motivated by professional opportunities. They also found that altruism was the main motivator and added that the nurses feel positive when both colleagues and organization appreciate and support them through education, supervision, training, mentoring opportunity and appropriate pay. Therefore, for employees who derive their satisfaction from external stimuli, opportunity for growth is an important motivational tool. According to Katsikitis et al. (2013) the effect of employee empowerment on job outcomes is a noted factor. In their study to test current understanding of continuing professional development, practice and future needs of nurses and midwives, as well as perceived barriers and incentives for continuing professional development, Katsikitis and colleagues noted that the respondents valued on-going learning and preferred education to occur within work hours and considered their hospitals as agreeable to change. Meanwhile, about two thirds of the respondents believed that responsibility for continuing professional development should be a shared one - between them and their employers. But where due to improper alignment of motivation variables, and where employees could clearly perceive that their future aspirations may not be met in their current employment, they are likely to call it quits (Rodwell \& Demir, 2013). It is, therefore, postulated that:

\section{$H_{I}$ : There is a significant relationship between opportunity for growth and turnover intentions}

\section{$\mathrm{H}_{2}$ : There is a significant relationship between opportunity for growth and psychological contract breach}

Workers contribution differs at various career stages of the employment exchange. At any given stage of employment, the personal career development and aspirations of the employee determines the types of contribution to offer and inducement to expect. The stages of employee career development could start from exploration to 
graduation and through to establishment, maintenance and disengagement. At exploration stage, employee inducements are largely in pursuit of self-centred career choices. At establishment stage, employee's career choices tend to synchronize with organizational objectives and workplace success. At maintenance stage employees look at work-life balance where workplace success is pursued alongside the pursuit of personal interests including family and social life as well as leisure. At disengagement stage employees prepare to leave the organization and their interest is largely about after-work life consideration. At any of these stages in the employment life cycle, the content of psychological contract and the impact of breach could be appreciated and felt differently by different employee categories (Low et al., 2016). For instance, the understanding of psychological contract by new entrants could be different from long serving staff. This is because factors such as benefits, task variety, and prospects for career progression could induce part-time workers lowly and cannot be the same for full-time employees who may value them highly.

A considerable number of nurses start their new job at a time they had not taken up family responsibilities, and have as well not had any previous employment experiences. Therefore, the scope and format or the premises for their psychological contract may be limited, thereby exposing them to lower perception of psychological contract breaches. However, the underlying bases for long serving staff psychological contract could differ significantly from those of the new staff. By this time, the employees had added value to themselves through skills acquisition and experience, and their consciousness for fairness, justice and social responsibility had enhanced. This could make them more prone to perception of psychological contract breaches because as they remain longer in an organization they begin to think that they have made considerable investment in the organization (Bankins, 2014).

In their study to find the extent to which family union could affect psychological contract violation among Chinese and American samples Xu et al. (2018) found that among Chinese male respondents, violation and turnover was significant while the relationship among female respondents was insignificant. This study shows that gender as well as the scope of familial responsibilities determines the extent of employees' psychological contract fulfilment or otherwise (Rodwell \& Demir, 2013). Since family union and connectedness have been found to be relevant in the assessment of the status of nurses' psychological contract, it follows that any transfer policy which fails to account for these correlates is likely to suffer similar fate. In other words, where nurses choose to work reflects the scope of family responsibilities, and so, where this is varied to their disadvantage they are likely to experience psychological contract breach, a position supported by Xu et al., (2018). It is, therefore, hypothesized that:

$H_{3}$ : Desire for family union will be significantly related to psychological contract breach

$H_{4}$ : Transfer policy will be significantly related to psychological contract breach

\section{$H_{5}$ : Transfer policy will be statistically related to turnover intentions}

Job involvement has been defined as the extent to which employees are made to contribute to work activity (Schaufeli et al., 2002). However, the nature of employees' motivation determines their readiness to deliver at optimal levels. With some employees, their motivation is derived from the extent to which they are engaged in the work processes. Such employees have internal locus of control and their satisfaction depends on how effectively they are able to contribute to organizational goals. With others who need prodding to function at their best, organizational arrangements, processes and events have to be planned with them in mind. According to Katou (2015), human resource process higher in content, has a stronger impact on organizational performance; adding that the reward system, as well as training components of human resource management is effective catalysts for organizational performance. This is also to say, when human resource process (reward and training) constitute employee psychological contract, their provision grant them the needed satisfaction to up their performance. But where due to misalignment of priorities, organizations limit or scrap rewards and training systems, employees whose psychological contract depend on them would be psychologically drained and would be unwilling to give of their best (Fu \& Cheng, 2014).

According to Wang and Liu (2013), nurses experience job satisfaction when the work environment is supportive, when there are adequate number of tools and equipment, and when support of colleagues and management are in place. Tanaka et al. (2014) postulate that indicators for psychological contract fulfilment among nurses are the levels of job involvement and the extent to which professional values are upheld, and their associated intrinsic and extrinsic motivational packages provided. Other studies have shed more light on the role of improved job involvement and patient care. For instance, according to Kasekende (2017), the level of employee engagement is a necessary condition for employer-employee relationship, more importantly relative to their extra-role behaviours. Thus, employees are psychologically fulfilled to the extent that they are fully engaged in their work. For such employees, their satisfaction may not be based on material rewards only; but also on when they are able to perform effectively towards organizational goals. 
Rahman et al. (2017) on the other hand, found context as very significant. Their study on team orientation as an effective productive tool found that though work engagement and relational psychological contract are highly correlated, context is very relevant in as far as job performance and job satisfaction are concerned. They opine that employees with high team orientation demonstrate high commitment when they are involved in decision making. They feel a sense of self-worth, confidence, resilience and their self-esteem is enhanced. Becoming a part of the organization's family in itself is a form of psychological contract fulfilment for such employees. It is, therefore, hypothesized that:

\section{$H_{6}$ : There is a significant relationship between job involvement and psychological contract breach}

Turnover intention is about any seriously thinking and actively prospecting by an employee for a new or a better job; or a desire to change a place of work within a specified period (Freese, 2007). According to Chenoweth et al. (2010), factors which influence employees' turnover intention are multifaceted; including which are workplace factors and demographic factors. This is also reinforced by Hung and Chin (2013) who found adversity quotient and gender as incidental to psychological contract breach and turnovers. According to this study, when nurses experience breach, they become emotionally and psychologically drained, a condition which forces some of them to ask for transfers. This is, therefore, to say that when employees do not find personal fulfilment in their work because their psychological contract has been breached, they are likely to show less interest in the organization and begin to find their way elsewhere (Flower et al., 2015; Ellershaw et al., 2014). It is, therefore, proposed that:

\section{$H_{7}$ : Psychological contract will be positively related to turnover intentions}

It is instructive to note that available empirical literature has established a relationship between opportunity for growth, transfer policy, family union and job involvement on one hand, and turnover intention on the other hand (Xu et al., 2018). Nonetheless, in their study to consider the relative impact of workplace bullying and friendship among an Indian sample, Rai and Agarwal (2018) found that psychological contract violation has no direct effect on employee outcomes. Instead, psychological contract violation mediates the relationship between intention to quit, job satisfaction as well as engagement and workplace friendship. In other words, psychological contract violation did not lead to the stated behavioural outcomes; instead, it was a necessary condition for work engagement. Therefore, because promises, obligations and expectations constitute psychological contract, the relationship between any specific motivation items and a given outcome is likely to be due to a third variable. It is therefore, hypothesized that:

$H_{8}$ : Psychological contract breach will mediate the relationship between opportunity for growth, transfer policy, family union, job involvement and turnover intention*

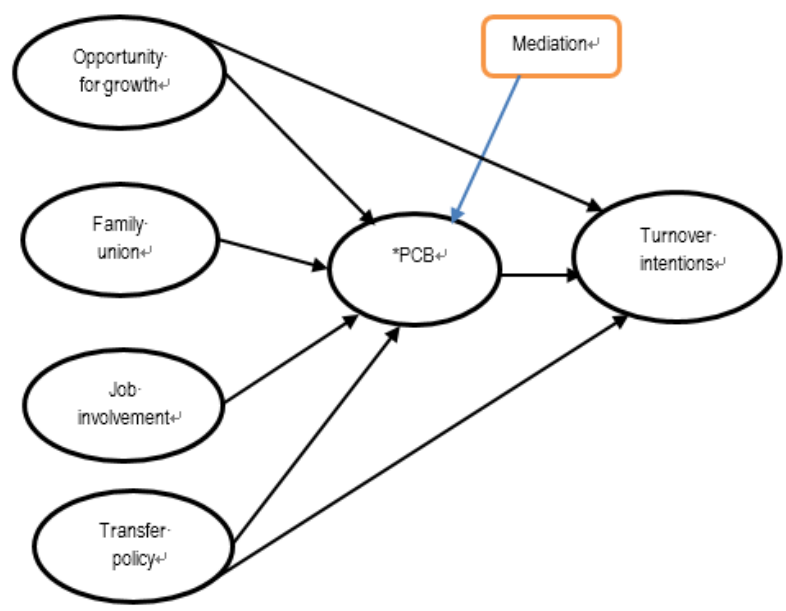

Figure 1. Linking motivational variables to turnover intentions

\section{Methods}

\subsection{Research Design}

The study adopted a cross-sectional design under the quantitative methodology to achieve the objective of the 
study. The choice of research design as well as approach was based on the fact that a large amount of data was gathered at a point in time and analysed statistically. The methods also enabled the researchers to have more control over how the data was gathered. Other considerations that the researchers gave were that data received from respondents came in the form of numbers, making it easy for the researchers to use statistical process to arrange them in tables and figures. This opened up the study to other scholars to replicate or repeat, given its high reliability. Using quantitative research design also ensured that the findings can be generalised to the study population. Additionally, the use of quantitative research to conduct the study was aimed at making predictions, establish facts and test already known hypotheses. In a way, the researchers were able to find evidence that either supports or does not support an existing hypothesis on leveraging on motivation to retain nurses, the role psychological contract plays. By using the quantitative research, therefore, the researchers were able to gather data that was precise, reliable and consistent.

The researchers used questionnaires as a tool to collect the data for the study. The researchers adapted global scales. According to Zhao et al. (2007), global scales have certain advantages over specific scale. Schaufeli et al. (2002)'s scale was adapted for job involvement. The seven- point Likert Scale was re-formatted to five. The instrument has questions such as: 'I am immersed in my work'; 'At my work I feel bursting with energy'; 'I find the work that I do full of meaning and purses'. Family union, transfer policy and opportunity for growth constructs were adapted from Karasek et al. (1998)'s Job Content Questionnaire. For psychological contract breach construct, Robinson and Morrison (2000)'s instrument was used. This is a five-point Likert type questionnaire which asked respondents to tick the most appropriate set of questions, e.g. "Almost all of the promises made by my employer during recruitment have been kept so far' (Reversed); 'My employer has broken many of its promises to me even though I have upheld my side of the deal', etc. For turnover intentions construct, Freese (2007) instrument was adapted. All the instruments were formatted to reflect the characteristics of the health sector.

Graduate nurses, midwives, staff nurses, community health nurses and health assistants from five mission hospitals in Bono East Region of Ghana made up the study population. With the assistance of the Matrons and the Health Service Administrators, the questionnaires were distributed to the respective nurses for their study. Paper boxes were placed at the Nursing Bays of some of the health facilities between $2^{\text {nd }}$ and $15^{\text {th }}$ December 2018 for the completed questionnaire to be placed into them while for other places, representatives of the nurses were tasked to gather the finished questionnaire (Table 1 below presents information on questionnaire distribution). Out of the 500 questionnaires distributed, 400 were returned, representing $80 \%$. The high response rate of the questionnaires was due to the high interest showed by the Administrators of the health facilities. This was followed by a manual process of cleaning to remove improperly filled questionnaires, as well as those with missing values. A sample size (n) of 350 questionnaires was captured on Microsoft Excel 2010, which was saved with file extension (csv comma delimited) and later transported to smartPLS 3 SEM for analysis.

Table 1. Showing information on the questionnaire distribution

\begin{tabular}{llll}
\hline \multirow{2}{*}{ NAME OF HOSPITAL } & NUMBER & NUMBER & PERCENTAGE \\
RESPONSE \\
DISTRIBUTED & RETURNED & RATE \\
\hline Ahamdiyya Muslim Hospital, Techiman & 45 & 40 & $89 \%$ \\
Holy Family Hospital, Techiman & 160 & 118 & $74 \%$ \\
St. Theresa's Hospital, Nkoranza & 130 & 105 & $81 \%$ \\
Methodist Hospital, Wenchi & 138 & 111 & $80 \%$ \\
Seventh Day Adventist Hospital, & 27 & 26 & $96 \%$ \\
Techiman & & & \\
\hline
\end{tabular}

Source: Researchers 2018.

SmartPLS3, a variant of Structural Equation Model was used to analyse the data for the study. In using the SmartPLS3, the researchers followed all the three stages for analysing PLS-SEM that have been stated as model specification; outer model and inner model evaluation. While model specification deals with structuring of the whole model, the outer model (measurement model) is about the relationship between the construct and its loadings (indicators). Meanwhile, the structural model deals with the inter-construct relationships. According to Henseler et al. (2012), in the assessment of SmartPLS, there is the need to state both inner and outer models before PLSSEM algorithm is run. This is followed by evaluating the reliability and validity of the construct's outer models. Similarly, Chin (1998) states that in the assessment of SEM model for reliability and validity, the measurement model should be tested first and when found to be acceptable (based on the recommended threshold or rule of 
thumb) the researcher could then proceed to test the structural model for the relationships between the latent construct.

\section{Results and Research Analysis}

The researchers used both descriptive and inferential statistics for the study analysis. Table 1 provides demographic information of the respondents.

Table 2. Demographic information of the sample

\begin{tabular}{|c|c|c|c|}
\hline Variable & Options & No. of & Percentage (\%) \\
\hline & & Respon & \\
\hline \multirow[t]{2}{*}{ Gender } & Male & 124 & 35.40 \\
\hline & Female & 226 & 64.60 \\
\hline \multirow[t]{4}{*}{ Age } & $21-30$ & 154 & 44.00 \\
\hline & $31-40$ & 144 & 41.10 \\
\hline & $41-50$ & 41 & 11.70 \\
\hline & $51-60$ & 11 & 3.10 \\
\hline \multirow[t]{2}{*}{ Marital status } & Married & 192 & 54.90 \\
\hline & Single & 158 & 45.10 \\
\hline Employment & Permanent & 284 & 81.10 \\
\hline \multirow[t]{2}{*}{ status } & Contract & 64 & 18.30 \\
\hline & Casual & 2 & 0.60 \\
\hline Length of & $1-10$ & 323 & 92.30 \\
\hline \multirow[t]{3}{*}{ employment } & $11-20$ & 21 & 6.00 \\
\hline & $21-30$ & 3 & 0.86 \\
\hline & $31-40$ & 3 & 0.86 \\
\hline Educational & Degree & 43 & 12.30 \\
\hline \multirow[t]{2}{*}{ qualification } & Diploma & 221 & 63.10 \\
\hline & Certificate & 86 & 24.60 \\
\hline
\end{tabular}

\subsection{Measurement Model Analysis}

To test the construct reliability, the researchers used information on Cronbach's alpha and rho_A. Values contained in Table 3, section 1 provide a substantial evidence for the construct reliability (Cronbach's alpha \& rho_A $>0.70$ ). For the Convergent Validity, the researchers used AVE and Composite Reliability values (Information contained in Table 3, section 2 exceeds the recommended threshold of $>0.50$ ). Also, the researchers used Fornell-Larcker (1981) criterion as well as Heterotrait Monotrait ratios for the Discriminant Validity. All the two measures met the recommended criteria that; (a) AVE of a latent construct should be greater than the highest squared inter-construct correlations (Fornell \& Larcker, 1981), and (b) HTMT <0.85 (Henseler, Ringle \& Sarstedt, 2015). 
Table 3. Construct reliability and validity

\begin{tabular}{lllll}
\hline Latent & Cronbach's & rho_A & AVE & CR \\
\hline Variable & Alpha & & & \\
FR & 0.871 & 0.798 & 0.630 & 0.894 \\
JI & 0.863 & 0.898 & 0.786 & 0.916 \\
OG & 0.849 & 1.648 & 0.601 & 0.856 \\
PCB & 0.932 & 0.936 & 0.832 & 0.952 \\
TP & 0.908 & 0.953 & 0.727 & 0.930 \\
TOI & 0.961 & 0.961 & 0.927 & 0.974 \\
\hline
\end{tabular}

Note. $\mathrm{AVE}=$ Average Variance Extracted; $\mathrm{CR}=$ Composite reliability.

Table 4. Fornell-Larcker Criterion

\begin{tabular}{|c|c|c|c|c|c|c|}
\hline $\begin{array}{l}\text { Latent } \\
\text { Variable }\end{array}$ & $\mathrm{FU}$ & JI & OG & PCB & ТP & TOI \\
\hline Family union & 0.790 & & & & & \\
\hline Job involvement & 0.211 & 0.890 & & & & \\
\hline Opportunity for growth & 0.108 & -0.262 & 0.780 & & & \\
\hline Psychological contract breach & -0.211 & -0.190 & -0.15 & 0.910 & & \\
\hline Transfer policy & 0.155 & 0.108 & 0.043 & -0.26 & 0.853 & \\
\hline Turnover intention & 0.149 & 0.102 & 0.043 & -0.58 & 0.102 & 0.963 \\
\hline
\end{tabular}

Notes. FU=Family union; JI=Job performance; $\mathrm{OG}=$ Opportunity for growth; $\mathrm{PCB}=$ Psychological contract breach; $\mathrm{TP}=$ Transfer policy; TOI=Turnover intentions.

Table 5. Heterotrait Monotrait ratio of correlation

\begin{tabular}{llllll}
\hline $\begin{array}{l}\text { Latent } \\
\text { Variable }\end{array}$ & FU & JI & OG & PCB & TP \\
\hline Family union & & & & \\
Job Involvement & 0.204 & & & \\
Opportunity for growth & 0.119 & 0.423 & 0.106 & 0.265 \\
Psychological contract & 0.191 & 0.21 & 0.101 & 0.616 & 0.097 \\
Transfer policy & 0.159 & 0.142 & 0.100 & \\
Turnover Intention & 0.135 & 0.106 &
\end{tabular}

Note. $\mathrm{FU}=$ Family union; JI=Job performance; $\mathrm{OG}=$ Opportunity for growth; $\mathrm{PCB}=$ Psychological contract breach;

$\mathrm{TP}=$ Transfer policy; TOI=Turnover intentions.

\subsection{Structural Model Assessment}

With the high psychometric properties for the latent constructs in the model established, the researchers tested the 
hypothesized paths of the Model. A bootstrapping procedure involving 5000 resampling with replacement was carried out. To test the fitness of the model, Standardized Root Mean Residual (SRMR) value was assessed. Evidence showed a good fit for the Model. In assessing the path coefficients, the sign, the magnitude and their significance were looked at. Table 6 shows information on the path coefficients.

Table 6. Path coefficients

\begin{tabular}{|c|c|c|c|c|c|c|}
\hline $\begin{array}{l}\text { Latent } \\
\text { construct }\end{array}$ & $\begin{array}{l}\text { Original } \\
\text { Sample (O) }\end{array}$ & $\begin{array}{l}\text { Sample } \\
\text { Mean (M) }\end{array}$ & $\begin{array}{l}\text { Standard } \\
\text { Deviation (STDEV) }\end{array}$ & $\begin{array}{l}\text { T Statistics } \\
(|\mathrm{O} / \mathrm{STDEV}|\end{array}$ & P Values & Decision \\
\hline Family Union -> PC & -0.119 & -0.129 & 0.046 & 2.583 & 0.010 & Supported \\
\hline Job Involvement $->$ PC & -0.190 & -0.190 & 0.054 & 3.496 & 0.001 & Supported \\
\hline Job Involvement $->$ Turnover Intention & -0.006 & -0.008 & 0.050 & 0.128 & 0.898 & Not supported \\
\hline Opportunity for growth $->\mathrm{PC}$ & -0.181 & -0.180 & 0.081 & 2.223 & 0.027 & Supported \\
\hline Psycho. contract $->$ Turnover Intention & -0.598 & -0.599 & 0.041 & 14.60 & 0.000 & Supported \\
\hline Transfer policy -> PC & -0.209 & -0.208 & 0.055 & 3.824 & 0.000 & Supported \\
\hline Transfer policy -> Turnover Intention & -0.051 & -0.047 & 0.048 & 1.060 & 0.290 & Not supported \\
\hline
\end{tabular}

As shown in table 4, there is strong evidence to support the researchers' hypothesis that there is a significant relationship between family union and psychological contract breach $(\beta=-0.119 ; p=0.010)$; significant relationship between job involvement and psychological contract breach $(\beta=-0.190 ; p=0.001)$; significant relationship between opportunity for growth and psychological contract breach $(\beta=-0.181 ; p=0.027)$; significant relationship between psychological contract breach and turnover intention $(\beta=-0.598 ; \mathrm{p}=0.000)$; and significant relationship between transfer policy and psychological contract breach $(\beta=-0.209 ; \mathrm{p}=0.000)$. On the other hand, there was no evidence to support the researchers' assumption that there would be a significant relationship between job involvement and turnover intention $(\beta=-0.006 ; p=0.898)$, as well as significant relationship between transfer policy and turnover intention $(\beta=-0.051 ; \mathrm{p}=0.290)$.

\subsection{Mediation Analysis}

In hypothesis $\mathrm{H}_{8}$, the researchers postulated that psychological contract breach will mediate the relationship between opportunity for growth and turnover intention, transfer policy and turnover intention, family union and turnover intention, and job involvement and turnover intentions. Results from Tables $6 \& 7$ indicate complementary partial mediation and supports the researchers' hypotheses. In other words, the relationship between family union and turnover intention was mediated by psychological contract breach; the relationship between job involvement and turnover intention was mediated by psychological contract breach; the relationship between opportunity for growth and turnover intention was mediated by psychological contract breach and the relationship between transfer policy and turnover intention was mediated by psychological contract breach.

In a complementary partial mediation, the signs (positive or negative) of both the direct and indirect effects must face the same direction (Baron \& Kenny, 1986). When both the 'Observed' values of indirect and direct effects are positive and statistically significant, it means that the mediator has possibly absorbed part of the effect of the independent variable on the dependent variable (Zhao et al., 2010). For instance, psychological contract was to mediate the relationship between family union and turnover intention in the researchers' model. In tables 7 (Indirect effect) \& 8 (direct effect), the values of the Observed (O) i.e. $\beta=0.071$ were all positive, and correspondingly, statistically significant at $\mathrm{p}=0.010$. 
Table 7. Total indirect effect (Indirect effect of mediation)

\begin{tabular}{|c|c|c|c|c|c|}
\hline Latent & Original & Sample & Standard & T Statistics & P Values \\
\hline construct & Sample (O) & Mean (M) & Deviation (STDEV) & $(|\mathrm{O} / \mathrm{STDEV}|)$ & \\
\hline Family union $->$ Turnover Intention & 0.071 & 0.077 & 0.028 & 2.582 & 0.010 \\
\hline Job Involvement $->$ Turnover Intention & 0.114 & 0.114 & 0.033 & 3.422 & 0.001 \\
\hline Opportunity growth $->$ Turnover Intention & 0.108 & 0.108 & 0.05 & 2.178 & 0.030 \\
\hline Transfer policy -> Turnover Intention & 0.125 & 0.124 & 0.032 & 3.854 & 0.000 \\
\hline
\end{tabular}

Table 8. Specific indirect effect (Specific effect)

\begin{tabular}{|c|c|c|c|c|c|}
\hline Latent & Original & Sample & Standard & T Statistics & P Values \\
\hline construct & Sample (O) & Mean (M) & Deviation (STDEV) & $(|\mathrm{O} / \mathrm{STDEV}|)$ & \\
\hline Family Union $->$ PC $->$ Turnover Intention & 0.071 & 0.077 & 0.028 & 2.582 & 0.010 \\
\hline Job Involvement $->$ PC $->$ Turnover Intention & 0.114 & 0.114 & 0.033 & 3.422 & 0.001 \\
\hline $\begin{array}{l}\text { Opportunity for growth }->\text { PC }->\text { Turnover } \\
\text { Intention }\end{array}$ & 0.108 & 0.108 & 0.05 & 2.178 & 0.030 \\
\hline Transfer policy -> PC -> Turnover Intention & 0.125 & 0.124 & 0.032 & 3.854 & 0.000 \\
\hline
\end{tabular}

\section{Discussions and Managerial Implications}

The study into how to leverage on motivation to retain nurses in mission hospitals in Ghana unearths interesting variables worthy of consideration by HRM as they add important perspectives to the body of knowledge in HRM. The study reveals that psychological contract plays an important role in stay-or-quit decision of nurses; and emphasizes the point that organizations' effort at motivating staff should not be at odds with the critical elements of employees' motivational content. This is because, incongruence due to misunderstanding of motivation variables, as well as generational differences has the effect of robbing employees of their satisfaction and impetus to function at optimal levels (Coyle-Shapiro \& Kessler, 2000). The study also supports the extant literature which states that, to get the desired impact of motivational interventions, motivation should be renegotiated from time to time so that it can take account of changes in need trajectories of employees (Ozguner \& Ozguner, 2014).

Social model of motivation provides empirical basis for the relationship that must exist between family union and psychological contract breach (Graziano \& Tobin, 2013). Moreover, the inverse relationship between family union and psychological contract provides guidance to management on how best employee outcomes could be improved. It makes the point that, where nurses' psychological contract is the type which prioritizes family union and connectedness, denying them the most prized thing will amount to psychological contract breach. Likewise, job involvement and opportunity for growth are other two variables nurses considered critical to their interest. Ordinarily, employees want to work in an environment where appropriate tools and equipment as well as support systems are in place. Where job is designed so that it takes account of the peculiar needs of employees, and to also challenge and test their ingenuity and innovative acumen, psychological contract breach will be less reported.

Opportunity to achieve a worthwhile career goal is one motivational variable emphasized by the self-actualizing framework of motivation. As evinced by Toode et al. (2014), higher order needs motivate nurses beyond 35 years than they are to younger nurses who are largely self-directed and work to pursue lower order needs (safety, social and physiological). Thus, recognition, sense of achievement, growth, responsibility, and the work itself are variables which influence employee motivation, and this could be intrinsic or extrinsic motivation. It is therefore, not surprising that a bigger chunk of the sample whose age falls below 35 years (see table 2), considered these variables as critical to their continued stay at their current workplace. This findings is reinforced by Janssen, Jonge and Bakker (1999) who found that 'hedonism' decreases with age and as nurses' grow older, their higher order 
needs (self-actualization and esteem) decreases.

Therefore, in organizations where there are appropriate systems in place to help employees achieve their career goals, such employees do not only work to improve organizational outcomes but develop paternalistic tendencies towards the organization. Nonetheless, the relationships between the stated variables are not a strait jacket one; they are a complex maze of issues which takes account of employee developmental stages. For instance, Low and Bordia (2016) assert that the need sought by employees at any particular stage of their employment relations is in keeping with the contribution made. Where the employee is at either establishment, maintenance or disengagement stages of employment relationships, the type of contributions made reflect the inducement sought. If employees' career development aspirations could be found at 'establishment stage', such employees are likely to pursue selfcentered career choices. For instance, employees who are at the 'maintenance stage' go for career aspirations that look at work-life balance; such that as they work to improve work outcomes, they also pursue family and social life as well as leisure. Those who may find themselves at the 'disengagement stage' are interested in after-work life.

Additionally, the study provides empirical foundation for the relationship between transfer policy and turnover intentions (Chenoweth et al., 2010). Effectively, if postings and transfers are made without recourse to the need for connectedness and family union, the likelihood of some employees seeing a psychological drain is high. It asserts that the relationship that exists between family union, job involvement, opportunity for growth and transfer policy on one hand, and turnover intentions on the other hand, are due to psychological contract breaches. In other words, the reasons for which employees are likely to leave their organization is not only due to some links missing from motivational interventions, but also, other explanatory variables such as psychological contract breach. For instance, social needs of employees are addressed when the workplace environment makes it possible to freely interact with work mates and customers, as well as, the ease with which they can interact with other superiors. Safety needs are addressed when there are safe work conditions, job security and appropriate or commensurate compensation and benefits schemes. In terms of physiological needs, opportunity for rest periods and refreshment, physical comfort on the job and reasonable work hours must be available for all employees (Schermerhorn, 2001 cited in Ozguner \& Ozguner, 2014).

The policy implication arising from this study is that if cost cutting initiatives become the basis for denying employees their critical motivational needs, the associated cost of turnovers will end up eroding any possible gains. It seeks to sound the alarm bell to policy makers as well as management of mission hospitals that psychological contract breach could seriously impair employee motivation leading to separation.

\subsection{Ethical Issues Considered}

Christian Health Association of Ghana as well as Ahmadiyya Muslim Health Services who administer the respective health facilities gave ethical clearance to conduct this study.

\section{Limitations and Future Research Direction}

One of the weaknesses of this study could be the mode of questionnaire administration. As outlined in the study design, the research questionnaire was distributed through Matrons and Health Service Administrators. It is the view of the researchers that this approach could possibly influence the choice of answers provided. It is therefore, recommended that future studies should limit or avoid the involvement of a third party. Also, the cross-sectional research design has the potential to exclude some elements of the targeted population. Again, resource constraints limited the ability of the researchers to target a larger population for the study, and this could affect the generalization of the findings. It is the recommendation of the researchers therefore, that future studies should aim at longitudinal research approach since behavioural decisions fluctuates along time and circumstances.

\section{References}

Anderson, N., \& Schalk, R. (1998). The psychological contract in retrospect and prospect. Journal of Organizational Behaviour, 19, 637-647. https://doi.org/10.1002/(SICI)1099-1379(1998)19

Bankins, S. (2014). Delving into promises: Conceptually exploring the beliefs constituting the contemporary psychological contract. Journal of Management \& Organization, 20, 544-566. https://doi.org/10.1017/jmo.2014.42

Baron, R. M., \& Kenny, D. A. (1986). The moderator-mediator variable distinction in social psychological research, conceptual, strategic, and statistical considerations. Journal of Personality and Social Psychology, 5, 11731182. https://doi.org/10.1037//0022-3514.51.6.1173

Behery, M., Paton, R. A., \& Hussain, R. (2012). Psychological contract and organizational commitment: The 
mediating effect of transformational leadership. Competitiveness Review: An International Business Journal, 22(4), 299-319. https://doi.org/10.1108/10595421211247141

Campbell, S. (2006). Addressing nursing shortages in sub-Saharan Africa. Nursing Standard, 20(51), 46-51. https://doi.org/10.7748/ns2006.08.20.51.46.c4490

Chehade, H. M., \& Hajjar, S. T. (2016). An empirical study to examine the effect of realistic job preview on expectancies, personal goals and performance. International Journal of Business and Management, 11(2). http://dx.doi.org/10.5539/ijbm.v11n2p164

Chenoweth, L., Jeon, Y. H., Merlyn, T., \& Brodaty, H. (2010). What factors attract and retain nurses in aged and dementia care: a systematic literature review. Journal of Clinical Nursing, 19(1), 156-167. https://doi.org/10.1111/j.1365-2702.2009.02955.x

Chenoweth, L., Merlyn, T., Jeon, Y. H., Taif, F., \& Duffield, C. (2014). Attracting and retaining qualified nurses in aged and dementia care: outcomes from an Australian study. Journal of Nursing Management, 22, 234-247. https://doi.org/10.1111/jonm. 12040

Chin, W. W. (1998). The Partial Least Squares Approach to Structural Equation Modelling; in Modern Business Research Method. In Marcoulides, G. A. (Ed.), Mahwah (pp. 295-336). NJ: Lawrence Erlbaum Associates.

Conway, N., \& Briner, R. B. (2005). Understanding psychological contracts at work: A critical evaluation of theory and research, Oxford University Press. https://doi.org/10.1093/acprof:oso/9780199280643.001.0001

Corder, E., \& Ronnie, L. (2017). The role of the psychological contract in the motivation of nurses, Leadership in Health Services. https://doi.org/10.1108/LHS-02-2017-0008

Coyle-Shapiro, J., \& Kessler, I. (2000). Consequences of the psychological contract for the employment relationship: A large scale survey. Journal of Management Studies, 37(7), 903-930. https://doi.org/10.1111/1467-6486.00210

Dantas, M. J. P., \& Ferreira, A. P. (2015). Content and violation of the psychological contract among head nurses. Revista de Enfermagem Referencia Serie IV-no.4. http://dx.doi.org/10.12707/RIII13170

Deboever, D. E. (2015). How administrative and professional ideologies shape the psychological contract of head nurses: A qualitative study. Retrieved from https://lib.ugent.be/fulltxt/RUG01/002/214/623/RUG0100221462320150001 AC.pdf

Duffield, C., Graham, E., Donoghu, J., Graffiths, R., Bichel-Findlay, J., \& Dimitrelis, S. (2014). Why older nurses leave the workforce and the implications of them staying. Journal of Clinical Nursing, 24, 824-831. https://doi.org/10.1111/jocn.12747

Ebert, R. J., \& Griffin, R. W. (2012). Business Essentials (9th ed.). Prentice Hall.

Festing, M., \& Schafer, L. (2014). Generational challenges to talent management: A framework for talent retention based on the psychological contract perspective. Journal of World Business, 49, 262-271. https://doi.org/10.1016/j.jwb.2013.11.010

Flower, R., Demir, D., McWilliams, J., \& Johnson, D. (2015). Perceptions of fairness in the psychological contracts of allied health professionals, Asia-Pacific. Journal of Business Administration, 7(2), 106-116. https://doi.org/10.1108/APJBA-03-2015-0022

Fornell, C., \& Larcker, D. F. (1981). Evaluating Structural Equation Model with unobservable variables and measurement error. Journal of Marketing Research, 18(1), 39-50. https://doi.org/10.2307/3151312

Fragar, L. J., \& Depczynski, J. C. (2011). Beyond50 - challenges at work for older nurses and allied health workers in rural Australia: A thematic analysis of focus group discussions. Health Services Research, 11(42). Retrieved from http://www.biomedcentral.com/1472-6963/11/42

Freese, C. (2007). Organizational change and the dynamics of psychological contracts: a longitudinal study. Doctoral Dissertation, Tilburg University, Tilburg.

Fu, C., \& Cheng, C. (2014). Unfulfilled expectations and promises, and behavioral outcomes. International Journal of Organizational Analysis, 22(1), 61-75. https://doi.org/10.1108/ IJOA-08-2011-0505

Graziano, W. G., \& Tobin, R. M. (2013). The cognitive and motivational foundations underlying agreeableness. Handbook of cognition and emotion, 347-364.

Hair, J. F., Sarstedt, M., Ringle, C. M., \& Mena, J. A. (2012b). An assessment of the use of partial least squares structural equation modeling in marketing research. Journal of the Academy of Marketing Science, 40(3), 
414-433. https://doi.org/10.1007/s11747-011-0261-6

Henseler, J., Ringle, C. M., \& Sarstedt, M. (2014). A new criterion for assessing discriminant validity in variancebased structural equation modeling. Journal of the Academy of Marking Science. https://doi.org/10.1007/s11747-014-0403-8.

Henseler, J., Ringle, C. M., \& Sarstedt, M. (2015). A new criterion for assessing discriminant validity in variancebased structural equation modeling. Journal of the Academy of Marketing Science, 43(1), 115-135. https://doi.org/10.1007/s11747-014-0403-8

Herriot, P., \& Pemberton, C. (1995). New deals, the revolution in managerial careers. John Wiley and Sons.

Herzberg, F., Mausner, B., \& Snyderman, B. (1959). The motivation to work, New York, Wiley.

Holtz, B. C. (2013). Trust primacy: A model of the reciprocal relations between trust and perceived justice. Journal of Management, 39(7), 1891-1923. https://doi.org/10.1177/0149206312471392

Janssen, P. M., Jonge, J. E., \& Bakker, A. B. (1999). Specific determinants of intrinsic work motivation, burnout and turnover intentions: A study among nurses. Journal of Advanced Nursing, 29(6), 1360-1369.

Karasek, R., Brisson, C., Kawakami, N., Houtman, I., Bongers, P., \& Amick, B. (1998). The job content questionnaire (JCQ): An instrument for internationally comparative assessments of psychosocial job characteristics. Journal of Occupational Health Psychology, 3(4), 322-355. https://doi.org/10.1037//10768998.3.4.322.

Kasekende, F., Munene, J. C., Ntayi, J. M., \& Ahiauzu, A. (2015). The interaction effect of social exchanges on the relationship between organizational climate and psychological contract. Leadership \& Organization Development Journal, 36(7), 833-848. https://doi.org/10.1108/LODJ-01-2014-0007

Katou, A. A. (2015). The mediating effects of psychological contracts on the relationship between human resource management systems and organisational performance. International Journal of Manpower, 36(7), 1012-1033. https://doi.org/10.1108/IJM-10-2013-0238

Katsikitis, M., Mcallister, M., Sharman, R., Raith, L., Faithfull-Byrne, A., \& Priaulx, R. (2013). Continuing professional development in nursing in Australia: Current awareness, practice and future direction. A Journal for the Australian Nursing Profession. https://doi.org/10.5172/conu.2013.3394

Kok, P., Gelderblom, D., \& Zyl, J. V. (2006). Internal and international migration within Africa: Dynamics and determinants, Cape Town, Human Sciences Research Council. Retrieved from http://hdl.handle.net/20.500.11910/7108

Kurtessis, J. N., Eisenberger, R., Ford, M. T., Buffardi, L. C., Stewart, K. A., \& Adis, C. S. (2015). Perceived organizational support: A meta-analytic evaluation of organizational support theory. Journal of Management, 20(10), 1-31. Https://doi.org/ 10.1177/0149206315575554

Lee, H. W., \& Lin, M. C. (2014). A study of salary satisfaction and job enthusiasm - mediating effects of psychological contract. Applied Financial Economics, 24, 1577-1583. https://doi.org/10.1080/09603107.2013.829197

Lenthall, S., Wakerman, J. Opie, T., Dunn, S., MacLeod, M., Dollard, M., Rickard, G., \& Knight, S. (2011). Nursing workforce in very remote Australia, characteristics and key issues. Australian Journal Rural Health, 19, 32-37. https://doi.org/ 10.1111/j.1440-1584.2010.01174.x

Low, C. H., Bordia, P., \& Bordia, S. (2016). What do employees want and why? An exploration of employees' preferred psychological contract elements across career stages. Human Relations, 69(7), 1457-1481. https://doi.org/ 10.1177/0018726715616468

Maslow, A. H. (1943). A theory of human motivation. Psychological Review, 50(4), 370-396. https://doi.org/10.1037/h0054346

McCabe, T. J., \& Sambrook, S. (2013). Psychological contracts and commitment amongst nurses and nurse managers: A discourse analysis. International Journal of Nursing Studies, 50, 954-967. http://dx.doi.org/10.1016/j.ijnurstu.2012.11.012

O’Leary-Kelly, A. M., Henderson, K. E., Anand, V., \& Ashforth, B. E. (2014). Psychological contracts in a nontraditional industry: Exploring the implications for psychological contract development. Group \& Organization Management, 39(3), 326-360. https://doi.org/ 10.1177/1059601114525851

Ozguner, Z., \& Ozguner, M. (2014). A managerial point of view on the relationship between Maslow's hierarchy 
of needs and Herzberg's dual factor theory. International Journal of Business and Social Science, 5(7).

Purvis, L. J., \& Cropley, M. (2003). The psychological contracts of National Health Service nurses. Journal of Nursing Management, 11, 107-120. https://doi.org/10.1046/j.1365-2834.2003.00357.x

Quartey, P., \& Kwakye, E. (2009). The net benefit of migration: The case of migrant nurses from Ghana to the United Kingdom. Ghana Social Science Journal, 5(1-2), 62-83. Retrieved from http://ugspace.ug.edu.gh/handle/123456789/35039

Rahman, U., Rehman, A., Imran, M.K., \& Aslam, U. (2017). Does team orientation matter? Linking work engagement and relational psychological contract with performance. Journal of Management Development, 36(9), 1102-1113. https://doi.org/10.1108/ JMD-10-2016-0204

Rai, A., \& Agarwal, U. A. (2018). Workplace bullying and employee silence: A moderated mediation model of psychological contract violation and workplace friendship. Personnel Review, 47(1), 226-256. https://doi.org/10.1108/PR-03-2017-0071

Robinson, S. L., \& Morrison, E. W. (2000). The development of psychological contract breach and violation: A longitudinal study. Journal of Organizational Behavior, 21(5), 525-546. https://doi.org/10.1002/10991379(200008)21:5<525::AID-JOB40>3.0.CO;2-T

Rodwell, J. J., \& Demir, D. (2013). The blurring of attractive work practices across health care sectors. Public Personnel Management, 42(4), 588-602. https://doi.org/10.1177/0091026013496076

Rodwell, J., \& Ellershaw, J. (2016). Fulfil promises and avoid breaches to retain satisfied, committed nurses. Journal of Nursing Scholarship, 48(3), 1-8. https://doi.org/10.1111/jnu.12215

Rousseau, D. (1995). Psychological contract in organizations: Understanding written and unwritten agreements, California, Sage Publications.

Rowley, J. (1996). Motivation of staff in libraries. Library Management, 17(5), 31-35.

Sanjeev, M. A., \& Surya, A. V. (2016). Two factor theory of motivation and satisfaction: An empirical verification. Ann. Data. Sci., 3(2), 155-173. https://doi.org/ 1011007/s40745-016-0077-9

Schaufeli, W. B., Salanova, M., Gonzalez-Roma, V., \& Bakker, A. B. (2002). The measurement of engagement and burnout: A two sample confirmatory factor analytic approach. Journal of Happiness Studies, 3(1), 71-92. https://doi.org/10.1023/A:1015630930326

Scheel, T. E., Rigotti, T., \& Mohr, G. (2013). HR practices and their impact on the psychological contracts of temporary and permanent workers. The International Journal of Human Resource Management, 24(2), 285307. https://doi.org/10.1080/09585192.2012.677462

Shawn, C. (2014). Dutton, management philosophy, realistic job preview, and Weber. Journal of Management History, 20(2). https://doi.org/10.1108/JMH-10-2013-0045r

Tambe, S., \& Shanker, M. (2014). A study of OCB and its dimensions: a literature review. International Research Journal of Business and Management, 1, 67-73.

Tanaka, M., Taketomi, K., Yokemitsu, Y., \& Kawamoto, R. (2014). Professional behaviours and factors contributing to nursing professionalism among nurse managers. https://doi.org/10.1111/jonm.12264

Taylor, F. W. (1911). The principles of scientific management. New York: Parper \& Brothers.

Tekleab, A. G., Orvis, K. A., \& Taylor, M. S. (2013). Deleterious consequences of change in newcomers' employerbased psychological contract obligations. Journal of Business Psychology, 28, 361-371. https://doi.org/10.1007/s10869-012-9277-2

Tomprou, M., Nikolaou, I., \& Vakola, M. (2012). Experiencing organizational change in Greece: The framework of psychological contract. The International Journal of Human Resource Management, 23(2), 385-405. https://doi.org/10.1080/09585192.2011.561223

Toode, K. (2015). Nurses' Work Motivation: Essence and Associations, Academic Dissertation. Finland: Tempere University Press of Health Sciences.

Toode, K., Routasalo, P., Helminen, M., \& Suominen, T. (2014). Hospital nurses' individual priorities, internal psychological states and work motivation. International Nursing Review, 61, 361-370. https://doi.org/10.1111/inr.12122

Van Der Colff, J. J., \& Rothmann, S. (2014). Burnout of registered nurses in South Africa. Journal of Nursing 
Management, 22, 630-642. https://doi.org/10.1111/j.1365-2834.2012.01467.x

Vantilborgh, T., Bidee, J., Pepermans, R., Willems, J., Huybrechts, G., \& Jegers, M. (2015). Effects of ideological and relational psychological contract breach and fulfilment on volunteers' work effort. European Journal of Work and Organizational Psychology, 23(2), 217-230. https://doi.org/10.1080/1359432X.2012.740170

Walker, A. (2013). Outcomes associated with breach and fulfilment of the psychological contract of safety. Journal of Safety Research, 47, 31-37. https://doi.org/ 10.1016/j.jsr.2013.08.008

Wang, S. S., \& Liu, Y. H. (2013). Impact of professional nursing practice environment and psychological empowerment on nurses' work engagement: Test of structural equation modelling. Journal of Nursing Management. https://doi.org/10.111/jonm.12124

Xu, S., Wang, Y., \& Jin, J. (2018). Do employees actually intend to turnover when betrayed? Evidence from China and the USA. Nankai Business Review International, 9(2), 179-198. https://doi.org/10.1108/NBRI-12-20160046

Zhao, X., Lynch Jr., J. G., \& Chen, Q. (2010). Reconsidering Baron and Kenny: Myths and truths about mediation analysis. Journal of Consumer Research, 37(2), 197-206. URL: http://www.jstor.org/stable/10.1086/651257

\section{Copyrights}

Copyright for this article is retained by the author(s), with first publication rights granted to the journal.

This is an open-access article distributed under the terms and conditions of the Creative Commons Attribution license (http://creativecommons.org/licenses/by/4.0/). 